\title{
Neto fiskalni položaj županija od 20II. do 2013.
}

\author{
ANTO BAJO, MARKO PRIMORAC, PETAR SOPEK I MARIN VUCO
}

Glavni je cilj rada utvrditi neto fiskalni položaj županija, odnosno svih gradova i općina na prostoru svake županije. Analiza je obavljena za razdoblje od 20II. do 20I3. Po utvrđenim ključevima obavljena je raspodjela oko I29 mlrd. kuna prihoda i rashoda proračuna opće države po županijama i izračunate su njihove neto fiskalne pozicije. Od 2I županije (20 županija i Grad Zagreb), samo četiri bilježe pozitivnu neto fiskalnu poziciju. Najbolju prosječnu godišnju poziciju bilježi Grad Zagreb (I3,7 mlrd. kuna), Istarska (795 mil. kuna), Primorsko-goranska (73I mil. kuna) i Zagrebačka županija (I34 mil. kuna). Ostale županije bilježe negativne neto fiskalne pozicije od čega najslabiju (negativnu) imaju Vukovarsko-srijemska (I,69 mlrd. kuna godišnjeg manjka) i Osječko-baranjska županija (1,67 mlrd. kuna).

\section{UvOD}

Glavni je cilj rada utvrditi prostornu dimenziju proračuna opće države, odnosno koje su županije neto korisnici, a koje neto uplatitelji u proračun opće države (ukupni konsolidirani proračun države, jedinica lokalne i područne samouprave i izvanproračunskih korisnika). Temeljem utvrđenih ključeva od 2oII. do 20I3. simulirana je raspodjela po županijama I29 mlrd. kuna prihoda i rashoda (oko 90\%) proračuna opće države (po ESA 20Io metodologiji). Istraživanjem se želi potaknuti Vladu i Sabor na izradu proračuna opće države po lokacijskoj klasifikaciji. Raspodjela prihoda i rashoda proračuna opće države po županijama predstavlja dobru analitičku podlogu za rasprave o regionalnom preustroju ili o poboljšanju postojećeg modela decentralizacije (administrativne, upravne i fiskalne). Dobiveni rezultati istraživanja pokazuju opravdanost takvog pristupa.

\section{Proračun OPĆE DRŽAVE}

Ukupni prihodi proračuna opće države od 2OII. do 20I3. su prosječno oko I36,4 mlrd. kuna (4I,2\% BDP-a), a rashodi oko 156,9 mlrd. kuna (47,4\% BDP-a). U sklopu proračuna opće države, proračuni svih lokalnih jedinica iznose 15,5 mlrd. kuna, odnosno tek oko Io\% proračuna opće države. Stoga se u istraživanju prišlo analizi i rasporedu prihoda i rashoda proračuna opće države po županijama u iznosu od I29 mlrd. kuna.

\footnotetext{
${ }^{1}$ Autori zahvaljuju kolegama Saši Ljepoviću i Ireni Klemenčić na korisnim sugestijama i savjetima.
} 


\section{Tablica I.}

Ukupni prihodi i rashodi opće države (ESA 20IO metodologija), razdoblje 20II.-I3. (u mlrd. kn i \% BDP-a)

\begin{tabular}{|c|c|c|c|c|c|c|}
\hline \multirow{2}{*}{$\begin{array}{c}\text { ESA 20Io } \\
\text { metodologija }\end{array}$} & \multicolumn{3}{|c|}{ u mlrd. kuna } & \multicolumn{3}{|c|}{$\%$ BDP } \\
\hline & 2011. & 2012. & 2013. & 2011. & 2012. & 2013. \\
\hline Prihodi & I34,9 & I36,4 & I38,o & 40,6 & $4 \mathrm{I}, 3$ & $4 \mathrm{I}, 8$ \\
\hline Rashodi & $\mathrm{I6O}, 4$ & I55,I & $\mathrm{I} 55,2$ & 48,2 & 46,9 & 47,0 \\
\hline
\end{tabular}

Napomena: Podaci slijede metodologiju Europskog sustava nacionalnih i regionalnih računa (ESA 20Io) koja se primjenjuje od rujna 2014. Za Hrvatsku je posebno važna zbog fiskalnog nadzora u sklopu procedure prekomjernog proračunskog manjka. ${ }^{2}$

Izvor: DZS (20I4a)

Analizom je obuhvaćeno prosječno oko I29 mlrd. kuna (v. tablicu 2), raspoređenih prema lokacijskoj pripadnosti po županijama. To su prihodi i rashodi lokalne i središnje države (državni proračun i izvanproračunski fondovi), prikazani po županijama.

\section{Tablica 2.}

Ukupni prihodi i rashodi korišteni u analizi, razdoblje 20II.-I3. (u mlrd. kn i postotku ukupnih prihoda i rashoda opće države), po ESA 2010 metodologiji

\begin{tabular}{|c|c|c|c|c|c|c|}
\hline & \multicolumn{3}{|c|}{ u mlrd. kuna } & \multicolumn{3}{|c|}{$\%$ prihoda/rashoda } \\
\hline & 2011. & 2012. & 2013. & 2011. & 2012. & 2013. \\
\hline Prihodi & $\mathrm{I} 27,4$ & I3O,4 & $\mathrm{I} 29,4$ & 94,4 & 95,6 & 93,8 \\
\hline Rashodi & $\mathrm{I} 28,4$ & $\mathrm{I} 26,4$ & I3I,2 & 80,0 & $8 \mathrm{I}, 5$ & 84,6 \\
\hline
\end{tabular}

Izvor: izračun autora

U odnosu na širi obuhvat opće države (prema ESA 20Io), analizirani prihodi pokrivaju veći dio ukupnih prihoda - u prosjeku 94,6\%. Na rashodnoj strani, udio pokrivenosti je nešto manji (prosječno 82,I\%) zbog isključivanja određenih transakcija iz analiziranih rashoda.

\section{METODOLOGIJA ZA UTVRĐIVANJE NETO FISKALNE POZIGIJE}

Neto fiskalna pozicija županije podrazumijeva razliku ukupnih prihoda i rashoda poslovanja na području te županije ${ }^{3}$. Praćenje neto fiskalnih pozicija po županijama je važno za provedbu regionalne politike jer jasno pokazuje fiskalne kapacitete (sposobnosti prikupljanja prihoda) i potrebe lokalnih jedinica na području županija.

Za provedbu analize bilo je potrebno najprije analitički razraditi prihodnu i rashodnu stranu proračuna opće države, odnosno prikazati ih po lokacijskoj pripadnosti - području gdje su prihodi proračuna opće države prikupljeni i rashodi potrošeni. Metodološki okvir slijedio je naizgled jednostavnu logiku utvrđivanja ključeva kojima se stavke prihoda i rashoda raspoređuju po županijama. Zbog određenih specifičnosti (jednokratnog karaktera), pojedine stavke prihoda i primitaka te rashoda i izdataka su isključene iz analize. U nastavku se objašnjavaju osnovni metodološki koncepti, a podrobnija pojašnjenja mogu se dobiti od autora.

Razrada prihoda. Metodologija za razradu prihoda temelji se na ekonomskoj klasifikaciji i informacijama o pripadnosti prihoda pojedinoj razini proračuna opće države (državnom proračunu, izvanproračunskim

\footnotetext{
${ }^{2}$ U odnosu na nacionalnu metodologiju (koju objavljuje Ministarstvo financija), obuhvat opće države prema ESA 20Io dodatno uključuje javna poduzeća Hrvatske autoceste i Autocestu Rijeka-Zagreb, Hrvatsku radioteleviziju i HŽ Infrastrukturu, a lokalna država dodatno obuhvaća vlastite prihode i rashode pojedinih korisnika lokalnih proračuna. Značajna razlika između nacionalne i ESA 2010 metodologije je i u evidentiranju fiskalnih transakcija. Prema ESA 2oIo fiskalne transakcije evidentiraju se po načelu nastanka obveze (prema obračunskom načelu), a prema nacionalnoj metodologiji uglavnom na gotovinskom načelu (prihodi i rashodi se evidentiraju u trenutku uplate u proračun).

${ }_{3}^{3}$ Prihodi koji se prikupljaju na području županije ne podrazumijevaju samo prihode koji se evidentiraju u proračunima JLP(R)S, već sve prihode koji lokacijski pripadaju području određene županije (čak i one koji se evidentiraju u proračunu središnje države). Isto vrijedi i za rashode.
} 
fondovima, lokalnim proračunima). Razrađeni su prihodi poslovanja proračuna opće države te su iz analize isključene pojedine stavke prihoda i primitaka koji bi zbog svoje nepredvidivosti, jednokratnosti ili dvostrukog knjiženja mogle iskriviti sliku ${ }^{4}$. Za razradu prihodne strane korišteno je 27 ključeva koji su primijenjeni na 46 stavki prihoda (v. grafikon I). Najveći udio u razradi prihoda ima BDP uvećan za uvoz roba (DZS, 20I2; 20I3a; 20I4b), koji je kao ključ korišten za raspodjelu PDV-a i ostalih poreza na robu i usluge koji zajedno čine 3I\% promatranih prihoda. S udjelom od 29\% slijede podaci o bruto plaćama koji su korišteni za raspodjelu doprinosa po županijama (podaci Ministarstva financija; DZS, 2OI3b; 2OI4c). Nešto manje udjele imaju podaci o porezu na dohodak i prirezu (8\%) te ostale kategorije prihoda JLP(R)S (6\%) koje su preuzete u agregiranom obliku sa stranica Ministarstva financija (20I4).

\section{Grafikon I.}

Struktura najvažnijih ključeva za razradu prihoda, prosjek razdoblja 20II.-I3.

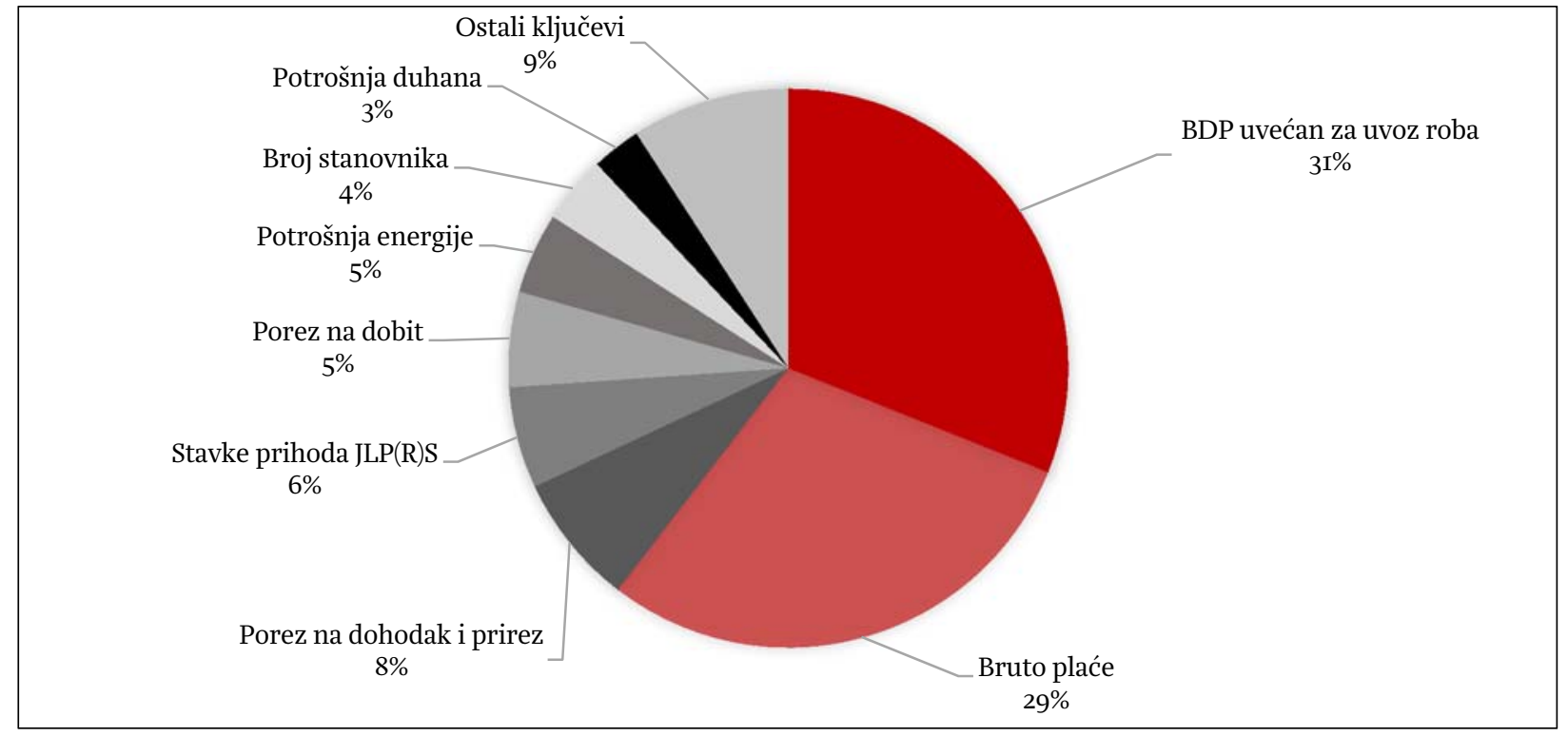

Izvor: izračun autora

Razrada rashoda. Rashodi proračuna opće države podijeljeni su po razinama vlasti na kojima se troše. Rashodi državnog proračuna detaljno su podijeljeni oslanjajući se na funkcijsku klasifikaciju. Unutar funkcija su prikazane pripadajuće organizacijske cjeline (ministarstva, uredi, službe itd.) čiji rashodi najvećim dijelom pripadaju u navedenu funkcijsku klasifikaciju ${ }^{5}$.

Raspodjela rashoda državnog proračuna po županijama obavljena je još detaljnije - po programima tih organizacijskih cjelina. Pored državnog proračuna, posebna podjela rashoda je napravljena za rashode JLP(R)S i izvanproračunske fondove. Iz analize su isključene pojedine stavke rashoda i izdataka: rashodi za nabavu nefinancijske imovine, rashodi za subjekte unutar općeg proračuna, izdaci za financijsku imovinu i zaduživanja, rashodi i izdaci subjekata javnog sektora koji nisu uključeni u obuhvat opće države. Rashodi JLP(R)S analizirani su po ekonomskoj namjeni (primjerice naknade zaposlenima, subvencije, pomoći itd.).

Zbog isključivanja stavki povezanih s transakcijama na nefinancijskoj imovini, na prihodnoj i rashodnoj strani te primitaka od izdataka za financiranje (financijska imovina i zaduživanje), izračunatu neto fiskalnu poziciju Republike Hrvatske ne smije se miješati sa službenom mjerom viška/manjka proračuna

\footnotetext{
${ }^{4}$ Iz analize su isključeni prihodi od prodaje nefinancijske imovine, prihodi od subjekata unutar općeg proračuna, te primici od financijske imovine i zaduživanja.

${ }_{5}$ Zbog razlika u metodologiji razrade prihodne i rashodne strane proračuna nije moguće jednoznačno raspoznati neto učinke po izvorima ili funkcijama - prihodi se ne mogu jednoznačno upariti s rashodima. Primjerice, na prihodnoj strani se pojavljuju doprinosi od mirovinskog osiguranja, a na rashodnoj cijeli rashod HZMO-a koji uključuje isplatu mirovina, ali i rashode za zaposlene i materijalne rashode Zavoda.
} 
opće države. S obzirom na kašnjenja pojedinih službenih statističkih informacija koje su korištene u raspodjeli rashoda, za pojedine godine koriste se zadnji dostupni podaci, premda se oni nužno ne odnose na pripadajuću godinu. Za razradu rashodne strane korištena su 44 različita ključa, primijenjena na I63 stavke rashoda (v. grafikon 2).

\section{Grafikon 2.}

Struktura najvažnijih ključeva za razradu rashoda, prosjek razdoblja 20II.-I3.

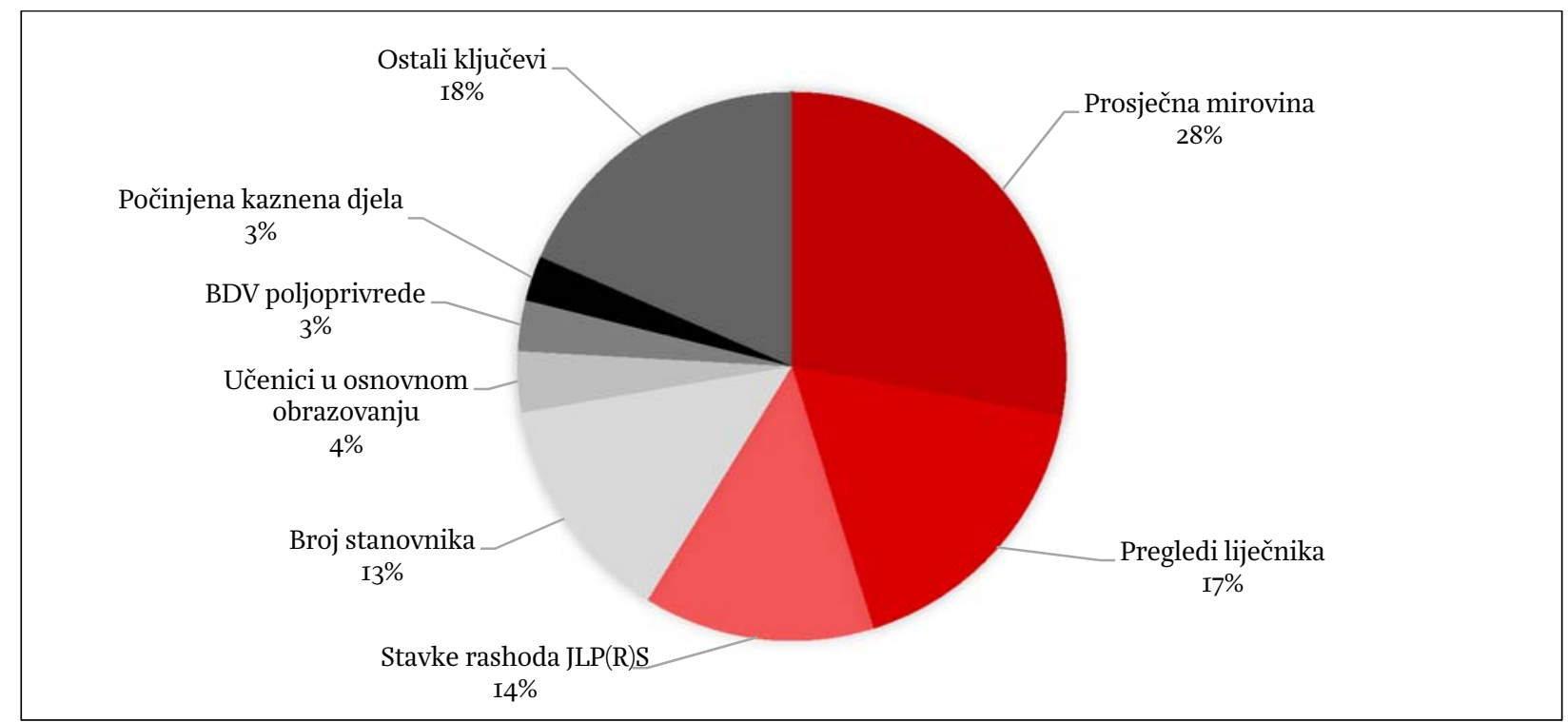

Izvor: izračun autora

Najveći udio u razradi rashoda po županijama ima iznos prosječne mirovine i broja umirovljenika (HZMO, 2OII; 2OI2; 2OI3), što se koristi kao ključ za raspodjelu rashoda Zavoda za mirovinsko osiguranje koji čine $28 \%$ promatranih rashoda. S udjelom od I7\% slijede podaci o broju pregleda liječnika (u ordinaciji i u kući) i upućivanja na specijalistički pregled (HZJZ, 2012; 2013; 20I4) koji su korišteni za raspodjelu rashoda povezanih sa zdravstvom - Hrvatski zavod za zdravstveno osiguranje, dio Ministarstva zdravlja te program zaštite, očuvanja i unapređenja zdravlja. Na trećem su mjestu podaci o pojedinačnim stavkama rashoda JLP(R)S (ukupno I4\%) koje su preuzete u agregiranom obliku sa stranica Ministarstva financija (20I4). S udjelom od I3\% ukupno promatranih rashoda slijede rashodi koji su po županijama podijeljeni po ključu broja stanovnika (DZS, 2OI4d), a koji se odnose na čak 72 proračunska korisnika ( uglavnom usluge od općeg javnog interesa i svih građana poput Vlade, Hrvatskog sabora, Državnog inspektorata, Ministarstva uprave, Ustavnog suda itd.).

\section{REZULTATI - NETO FISKALNE POZICIJE ŽUPANIJA}

Prosječna neto fiskalna pozicija na razini Republike Hrvatske je pozitivna i iznosi 383 mil. kuna. ${ }^{6}$ Međutim, provedena analiza po županijama pokazuje zabrinjavajuće rezultate. Od 2I županije, samo četiri su u razdoblju 20II.-I3. zabilježile pozitivnu neto fiskalnu poziciju.

Očekivano, najbolju prosječnu godišnju neto fiskalnu poziciju ima Grad Zagreb (13,7 mlrd. kuna)7, te Istarska (795 mil. kuna), Primorsko-goranska (73I mil. kuna) i Zagrebačka županija ( I34 mil. kuna). Ostale

\footnotetext{
${ }^{6}$ Valja podsjetiti da se izračunatu neto fiskalnu poziciju RH nikako ne smije miješati sa službenom mjerom viška/manjka proračuna opće države, jer se za potrebe ove analize razmatraju isključivo poslovni prihodi i rashodi (bez transakcija na nefinancijskoj imovini te bez primitaka od i izdataka za financiranje), kako je i objašnjeno u metodološkom dijelu.

${ }^{7}$ Grad Zagreb je kulturno, znanstveno, gospodarsko, političko i administrativno središte RH; ima najvišu razinu zaposlenosti - udio broja zaposlenih u ukupnom broju stanovnika u 20I3. iznosi $45 \%$ u odnosu na prosjek RH od 26\% (DZS, 2OI4C; 20I4d); ima i najviše prosječne neto plaće - u 20I2. prosječna neto plaća u Zagrebu iznosila je 6.366, a prosjek Hrvatske bio je 5.469 kuna (DZS, 2OI4c); oko polovice ukupne dobiti poduzetnika RH ostvaruju poduzeća sa sjedištem u Zagrebu (FINA, 2OI3) itd.
} 
županije bilježe negativne neto fiskalne pozicije od čega najslabiju ima Vukovarsko-srijemska (I,69 mlrd. kuna) i Osječko-baranjska županija (I,67 mlrd. kuna).

Tablica 3.

Ukupno analizirani prihodi, rashodi i neto fiskalne pozicije svih županija, prosjek razdoblja 20II.-I3. (u mil. kn)

\begin{tabular}{|c|c|c|c|c|}
\hline $\begin{array}{l}\text { Šifre } \\
\text { župan. }\end{array}$ & Żupanije & Prihodi & Rashodi & $\begin{array}{c}\text { Neto fiskalne } \\
\text { pozicije }\end{array}$ \\
\hline OI & Zagrebačka & 8.417 & 8.283 & I34 \\
\hline $\mathrm{O} 2$ & Krapinsko-zagorska & 2.964 & 3.709 & -746 \\
\hline $\mathrm{O} 3$ & Sisačko-moslavačka & 4.047 & 5.193 & -I.I46 \\
\hline $\mathrm{O} 4$ & Karlovačka & 3.188 & 3.920 & -732 \\
\hline $\mathrm{O} 5$ & Varaždinska & 4.277 & 4.726 & -449 \\
\hline o6 & Koprivničko-križevačka & 2.777 & $3 \cdot 385$ & -608 \\
\hline 07 & Bjelovarsko-bilogorska & $2.5 \mathrm{I} 3$ & 3.469 & -956 \\
\hline o8 & Primorsko-goranska & IO.5I9 & 9.788 & 731 \\
\hline O9 & Ličko-senjska & 1.263 & I.924 & -662 \\
\hline IO & Virovitičko-podravska & I.699 & 2.452 & -752 \\
\hline II & Požeško-slavonska & I.522 & 2.160 & -638 \\
\hline I2 & Brodsko-posavska & 2.969 & 4.II7 & -I.I48 \\
\hline I3 & Zadarska & 4.397 & 5.146 & -749 \\
\hline I4 & Osječko-baranjska & 7.113 & 8.787 & $-\mathrm{I} .674$ \\
\hline I5 & Šibensko-kninska & 2.686 & 3.529 & -844 \\
\hline I6 & Vukovarsko-srijemska & 3.387 & 5.076 & $-\mathrm{I} .689$ \\
\hline 17 & Splitsko-dalmatinska & II. 647 & I3.042 & -I.396 \\
\hline I8 & Istarska & 7.475 & 6.680 & 795 \\
\hline I9 & Dubrovačko-neretvanska & 3.520 & 3.969 & -449 \\
\hline 20 & Međimurska & 2.586 & 2.886 & -300 \\
\hline \multirow[t]{2}{*}{$2 \mathrm{I}$} & Grad Zagreb & 40.117 & 26.456 & I3.66I \\
\hline & Hrvatska & 129.083 & $\mathbf{I 2 8 . 7 0 0}$ & 383 \\
\hline
\end{tabular}

Izvor: izračun autora

Neto fiskalne pozicije županija po stanovniku županije u razdoblju 2OII.-I3. prikazane su u tablici 4.

Neto fiskalne pozicije županija po stanovniku tek djelomice se mijenjaju. I dalje najbolju neto fiskalnu poziciju drži Grad Zagreb - po stanovniku Grada u proračun opće države se u prosjeku uplati I7,2 tisuće kuna više nego što se iz njega potroši. Na drugom se mjestu nalazi Istarska županija koja bilježi prosječan višak od 3,8 tisuća kuna po stanovniku. Slijedi Primorsko-goranska županija s viškom od 2,5 tisuća kuna po stanovniku. Najslabiju neto fiskalnu poziciju ima Ličko-senjska županija s manjkom od čak 13,2 tisuća kuna po stanovniku županije.

Ne postoje značajnija odstupanja ukoliko se promatraju promjene po godinama. 


\section{Tablica 4.}

Ukupno analizirani prihodi, rashodi i neto fiskalne pozicije po stanovniku svih županija, prosjek razdoblja 2OII.-I3. ( $\mathrm{u} \mathrm{kn}$ )

\begin{tabular}{|c|c|c|c|c|}
\hline $\begin{array}{l}\text { Šifre } \\
\text { župan. }\end{array}$ & Županije & Prihodi & Rashodi & $\begin{array}{c}\text { Neto fiskalne } \\
\text { pozicije }\end{array}$ \\
\hline OI & Zagrebačka & 26.450 & 26.029 & $42 I$ \\
\hline $\mathrm{O} 2$ & Krapinsko-zagorska & 22.492 & $28.15 \mathrm{I}$ & -5.659 \\
\hline $\mathrm{O} 3$ & Sisačko-moslavačka & 23.892 & $30.66 I$ & -6.768 \\
\hline $\mathrm{O} 4$ & Karlovačka & 25.092 & $30.85 \mathrm{I}$ & -5.759 \\
\hline O5 & Varaždinska & 24.426 & 26.990 & -2.564 \\
\hline o6 & Koprivničko-križevačka & 24.172 & 29.464 & -5.292 \\
\hline 07 & Bjelovarsko-bilogorska & $2 \mathrm{I} .27 \mathrm{I}$ & $29.36 I$ & -8.090 \\
\hline o8 & Primorsko-goranska & $35.6 \mathrm{I} 6$ & 33.142 & 2.474 \\
\hline O9 & Ličko-senjska & 25.253 & 38.489 & $-\mathrm{I} 3.237$ \\
\hline IO & Virovitičko-podravska & 20.274 & 29.250 & -8.976 \\
\hline II & Požeško-slavonska & I9.830 & 28.144 & $-8.3 \mathrm{I} 4$ \\
\hline I2 & Brodsko-posavska & I8.9O2 & 26.207 & -7.305 \\
\hline I3 & Zadarska & 25.725 & 30.IO9 & -4.384 \\
\hline I4 & Osječko-baranjska & 23.496 & 29.024 & -5.528 \\
\hline I5 & Šibensko-kninska & 24.930 & 32.760 & -7.831 \\
\hline I6 & Vukovarsko-srijemska & 19.082 & 28.601 & -9.519 \\
\hline I7 & Splitsko-dalmatinska & $25.6 \mathrm{I} 3$ & 28.682 & -3.069 \\
\hline I8 & Istarska & 35.965 & 32.I4O & 3.826 \\
\hline I9 & Dubrovačko-neretvanska & 28.772 & 32.446 & -3.674 \\
\hline 20 & Međimurska & 22.765 & 25.407 & -2.642 \\
\hline \multirow[t]{2}{*}{$2 \mathrm{I}$} & Grad Zagreb & 50.589 & 33.362 & 17.227 \\
\hline & Hrvatska & 30.245 & 30.155 & 90 \\
\hline
\end{tabular}

Izvor: izračun autora

U 20I3. je u odnosu na baznu 20II. primjetno poboljšanje neto fiskalne pozicije po stanovniku u Šibenskokninskoj (rast I.o26 kuna po stanovniku) i Splitsko-dalmatinskoj županiji (rast 907 kuna po stanovniku). Usprkos pozitivnim trendovima u promatrane tri godine, u Šibensko-kninskoj i Splitsko-dalmatinskoj županiji je u 20I3. i dalje zadržana negativna neto fiskalna pozicija. Pozitivne trendove bilježe i Zadarska (243 kuna), Istarska (237 kuna), Varaždinska (227 kuna), Virovitičko-podravska (99 kn), Osječko-baranjska (85 kuna) i Brodsko-posavska županija (76 kuna). Među navedenim županijama jedino je na području Istarske županije zabilježena pozitivna neto fiskalna pozicija u tri promatrane godine, uz pozitivan trend u 20I3. u odnosu na 2011.

S druge strane, Ličko-senjska županija u cijelom razdoblju bilježi najslabiju neto fiskalnu poziciju $\mathrm{s}$ evidentnim trendom dodatnog pogoršanja u tri promatrane godine. Tako je samo u 20I3. neto fiskalna pozicija po stanovniku Ličko-senjske županije bila u minusu preko I5 tisuća kuna, što je 3.302 kune manje nego u 20II. Grad Zagreb je u promatranom razdoblju također zabilježio negativan trend, pa je 20I3. imao neto fiskalnu poziciju po stanovniku za 977 kuna manju nego u 2011. 
Tablica 5.

Neto fiskalne pozicije po stanovniku svih županija u razdoblju 20II.-I3. (u kn)

\begin{tabular}{|c|c|c|c|c|c|}
\hline $\begin{array}{c}\text { Šifre } \\
\text { župan. }\end{array}$ & Żupanije & $20 I I$. & 2012. & 2013. & $\begin{array}{c}\text { Promjene } \\
\text { 2013./20II. }\end{array}$ \\
\hline OI & Zagrebačka & 180 & $\mathrm{I}, \mathrm{O} 4 \mathrm{I}$ & 43 & -137 \\
\hline $\mathrm{O} 2$ & Krapinsko-zagorska & -5.922 & -4.601 & -6.459 & -537 \\
\hline O3 & Sisačko-moslavačka & -6.794 & -6.OII & -7.510 & -717 \\
\hline $\mathrm{O} 4$ & Karlovačka & -5.876 & -4.953 & -6.453 & -577 \\
\hline 05 & Varaždinska & -3.023 & -1.872 & -2.797 & 227 \\
\hline o6 & Koprivničko-križevačka & -5.542 & -4.406 & -5.930 & -388 \\
\hline 07 & Bjelovarsko-bilogorska & $-8.4 \mathrm{II}$ & -6.755 & -9.109 & -698 \\
\hline o8 & Primorsko-goranska & I. 856 & 3.835 & I.73I & $-\mathrm{I} 25$ \\
\hline 09 & Ličko-senjska & $-\mathrm{II} .975$ & -12.500 & -15.277 & -3.302 \\
\hline IO & Virovitičko-podravska & -9.339 & -8.349 & -9.240 & 99 \\
\hline II & Požeško-slavonska & -8.480 & -7.263 & -9.206 & -726 \\
\hline I2 & Brodsko-posavska & $-7.68 \mathrm{I}$ & -6.627 & -7.605 & 76 \\
\hline I3 & Zadarska & -4.752 & -3.893 & -4.509 & 243 \\
\hline I4 & Osječko-baranjska & -6.032 & -4.606 & -5.947 & 85 \\
\hline I5 & Šibensko-kninska & -8.672 & -7.161 & -7.646 & I.O26 \\
\hline I6 & Vukovarsko-srijemska & -9.492 & -8.375 & -10.700 & $-\mathrm{I} .208$ \\
\hline I7 & Splitsko-dalmatinska & -3.683 & -2.749 & -2.776 & 907 \\
\hline I8 & Istarska & $3.2 \mathrm{II}$ & 4.819 & 3.447 & 237 \\
\hline 19 & Dubrovačko-neretvanska & -3.882 & -2.264 & -4.876 & -994 \\
\hline 20 & Međimurska & -3.021 & $-\mathrm{I} .83 \mathrm{I}$ & -3.073 & -52 \\
\hline \multirow[t]{2}{*}{$2 \mathrm{I}$} & Grad Zagreb & $\mathrm{I} 7.258$ & I8.I43 & 16.282 & -977 \\
\hline & Hrvatska & -239 & 936 & -428 & -189 \\
\hline
\end{tabular}

Izvor: izračun autora

\section{ZAKLJUČAK}

Proračun Republike Hrvatske se ne prikazuje prema lokacijskoj klasifikaciji, što onemogućava praćenje fiskalne pozicije prema prostornoj (regionalnoj, županijskoj) dimenziji. Zbog toga se ne mogu analizirati Vladine politike i reforme ni procijeniti njihov učinak na regionalni razvoj i fiskalnu poziciju pojedinih regija.

Institut za javne financije izradio je metodologiju za lokacijsku klasifikaciju prihoda i rashoda po odabranim ključevima. Temeljem te metodologije moguće je utvrditi neto fiskalni položaj svake županije (prihoda koji se prikupljaju i rashoda koji se troše na području pojedine županije) te pružiti okvir za procjene vladinih politika i reformi usmjerenih prema regionalnom razvoju, ali i ocijeniti njihov utjecaj na prihode i rashode.

Rezultati analize ukazali su na postojanje određene neučinkovitosti u postojećem regionalnom ustroju. Samo su četiri od ukupno 2I županije neto uplatitelji, a ostalih I7 županija su neto primatelji iz proračuna opće države. Takav model regionalnog ustroja (u kojemu se na području velike većine županija troši više od uplata) očito nije dugoročno održiv.

Izložena metodologija otvara novu perspektivu praćenja fiskalne politike Republike Hrvatske na lokalnoj i regionalnoj razini. Za državu je to koristan instrument za preispitivanje regionalnih politika i kvalitetnijeg praćenja učinkovitosti instrumenata fiskalne politike na strani prihoda i rashoda po županijama. 
Rezultati analiza za jedinice lokalne i regionalne samouprave sa slabijim neto fiskalnim položajem (kao i za čelnike koji njima upravljaju) mogu biti motivacija za poboljšanje njihove fiskalne pozicije. Županijama koje ostvaruju najbolje rezultate to je svojevrsna potvrda uspješnosti koja im može pomoći u lobiranju za povećanje sredstava iz proračuna opće države ili dobar argument za daljnju decentralizaciju.

Ovim istraživanjem se želi potaknuti stručna rasprava o mogućim i potrebnim opcijama regionalnog preustroja Republike Hrvatske, temeljena na pokazateljima, a ne na subjektivnim ili općim dojmovima.

\section{Slika I.}

Mapa neto fiskalnih pozicija po stanovniku, prosjek razdoblja 20II.-I3. (u kn)

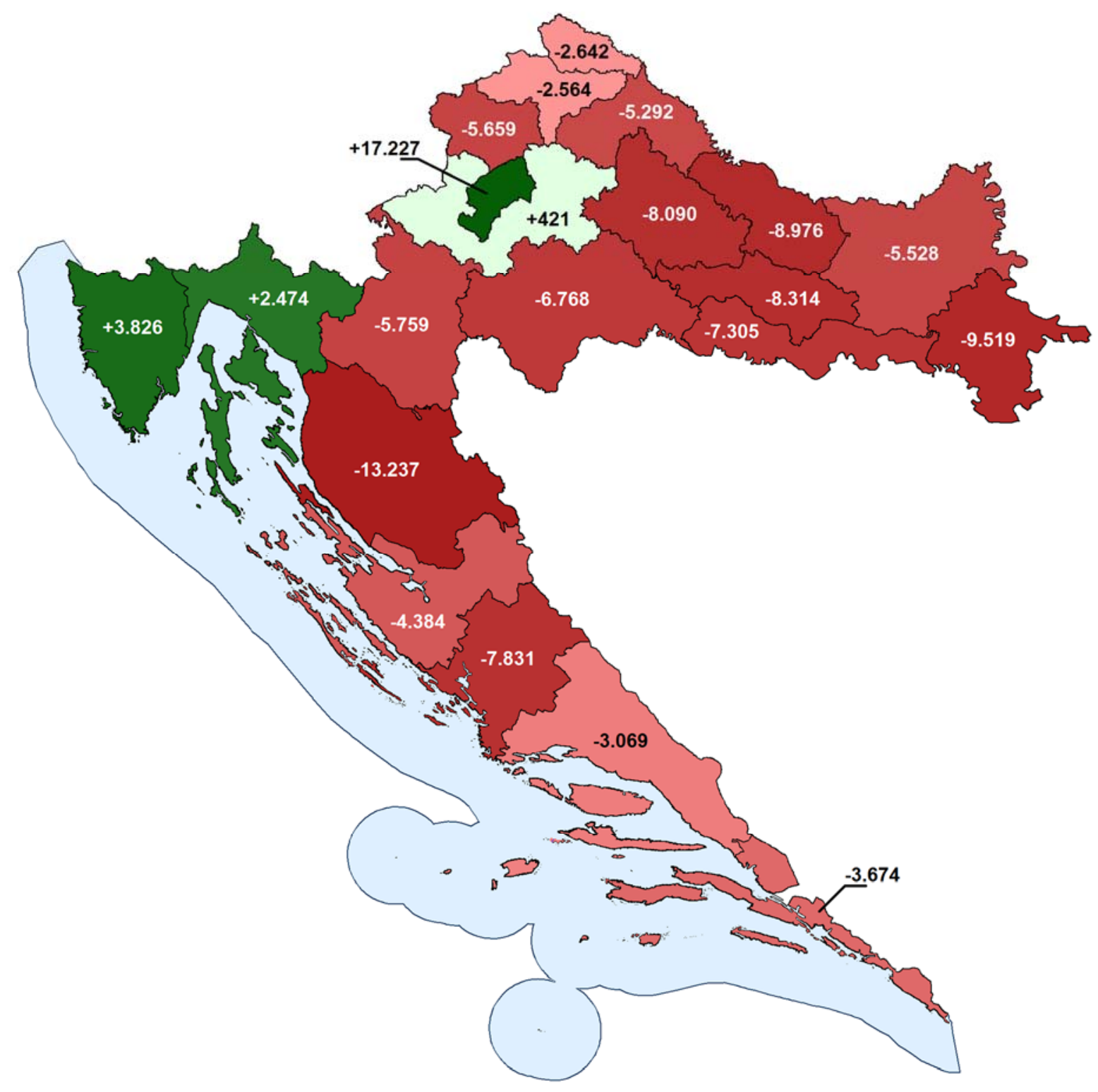




\section{LITERATURA}

DZS, 20I2. Statistički ljetopis Republike Hrvatske 20I2. Zagreb: Državni zavod za statistiku.

DZS, 20I3a. Statistički ljetopis Republike Hrvatske 20I3. Zagreb: Državni zavod za statistiku.

DZS, 20I3b. Zaposleni prema područjima djelatnosti i po županijama stanje 3I. ožujka 2OI2. Priopćenje, br. I2.I.2. Zagreb: Državni zavod za statistiku.

DZS, 2OI4a. Izvješće o prekomjernome proračunskome manjku i razini duga opće države u Republici Hrvatskoj, travanj 20I4. Priopćenje, br. I2.I.3/I. Zagreb: Državni zavod za statistiku.

DZS, 2OI4b. Bruto domaći proizvod za Republiku Hrvatsku, NKPJS - 2. razina i županije u 2OII. Priopćenje, br. I2.I.2. Zagreb: Državni zavod za statistiku.

DZS, 20I4c. Zaposleni prema područjima djelatnosti i po županijama stanje 3I. ožujka 20I3. Priopćenje, br. I2.I.2. Zagreb: Državni zavod za statistiku.

DZS, 20I4d. Procjene stanovništva Republike Hrvatske u 2OI3. Priopćenje, br. 7.I.4. Zagreb: Državni zavod za statistiku.

FINA, 2OI3. Osnovni financijski rezultati poduzetnika po županijama za 2OI2. godinu. Registar godišnjih financijskih izvještaja. Zagreb: Financijska agencija.

HZJZ, 20I2. Hrvatski zdravstveno-statistički ljetopis za 20II. godinu. Zagreb: Hrvatski zavod za javno zdravstvo.

HZJZ, 2OI3. Hrvatski zdravstveno-statistički ljetopis za 20I2. godinu. Zagreb: Hrvatski zavod za javno zdravstvo.

HZJZ, 20I4. Hrvatski zdravstveno-statistički ljetopis za 20I3. godinu. Zagreb: Hrvatski zavod za javno zdravstvo.

HZMO, 2OII. Statističke informacije Hrvatskog zavoda za mirovinsko osiguranje. Zagreb: Hrvatski zavod za mirovinsko osiguranje.

HZMO, 2OI2. Statističke informacije Hrvatskog zavoda za mirovinsko osiguranje. Zagreb: Hrvatski zavod za mirovinsko osiguranje.

HZMO 20I3. Statističke informacije Hrvatskog zavoda za mirovinsko osiguranje. Zagreb: Hrvatski zavod za mirovinsko osiguranje.

Ministarstvo financija, 20I4. Lokalni proračun - Arhiva. Zagreb: Ministarstvo financija. 